\title{
ASYMMETRIC COLD ROLLING OF AN AA 5xxx ALUMINIUM ALLOY
}

\author{
ASIMETRIČNO HLADNO VALJANJE ALUMINIJEVE ZLITINE \\ SERIJE AA 5xxx
}

\author{
Jakob Kraner ${ }^{1,2 *}$, Peter Fajfar², Heinz Palkowski³ ${ }^{3}$, Matjaž Godec', Irena Paulin'1 \\ ${ }^{1}$ Institute of Metals and Technology, Lepi pot 11, SI-1000 Ljubljana, Slovenia \\ 2Department of Materials and Metallurgy, Faculty of Natural Sciences and Engineering, University of Ljubljana, Aškerčeva cesta 12, SI-1000 \\ Ljubljana, Slovenia \\ ${ }^{3}$ Department of Metal Forming and Processing, Institute of Metallurgy, Faculty of Natural and Materials Science, Clausthal University of \\ Technology, Robert-Koch-Straße 42, DE-38678 Clausthal-Zellerfeld, Germany
}

Prejem rokopisa - received: 2020-06-03; sprejem za objavo - accepted for publication: 2020-06-05

\author{
doi:10.17222/mit.2020.097
}

Asymmetric rolling - a known industrial practice, but a rarely used metal-forming process - was applied to the EN AW 5454 aluminium alloy. The improvement in the technological parameters and the different mechanical properties was assessed by comparing the symmetric and asymmetric rolling procedures. The study was carried out with numerical simulations, mechanical tests and metallographic analyses. More homogeneous material with finer crystal grains and a much lower planar anisotropy was produced with asymmetric rolling and annealing to the soft condition compared to that with symmetric rolling. The textures of the asymmetrically rolled samples and the volume fraction of the separate texture components were different and more suitable for the heat treatment than the textures of the symmetrically rolled samples. The study revealed that the ski effect or a bended part of the rolled workpiece appeared during the numerical simulations as well as during laboratory rolling, but only with the asymmetric rolling.

Keywords: asymmetric rolling, mechanical properties, microstructures, texture components, EBSD

Asimetrično valjanje je bilo izvedeno na aluminijevi zlitini EN AW 5454. Gre za poznane, vendar redko uporabljene, procese preoblikovanja $\mathrm{v}$ industrijski praksi. Kot preizkus izboljšanja določenih tehnoloških lastnosti in različnih mehanskih lastnosti z asimetričnim valjanjem, so se rezultati le-teh primerjali s simetričnim valjanjem. V ta namen so bile izdelane in izvedene numerične simulacije, mehanski preizkusi in metalografska analiza. Bolj homogen material z manjšimi kristalnimi zrni in veliko manjšo površinsko anizotropijo, je bil proizveden $\mathrm{z}$ asimetričnim valjanjem in žarjenjem do mehkega stanja, kot s primerljivimi simetričnimi načini valjanja. Tekstura asimetrično valjanih vzorcev z volumskim deležem posameznih teksturnih komponent se je razlikovala in hkrati bila bolj primerna za nadaljnjo toplotno obdelavo kot pri simetrično valjanih vzorcih. Učinek upogiba oziroma upogib obdelovanca se je tako pri numeričnih simulacijah kot pri laboratorijskem valjanju, pojavil zgolj pri asimetričnih načinih valjanja.

Ključne besede: asimetrično valjanje, mehanske lastnosti, mikrostrukture, teksturne komponente, EBSD

\section{INTRODUCTION}

Symmetric rolling is normally used in industrial practice, but it is also possible to conduct a asymmetric rolling process. Asymmetry can be introduced in a rolling process in different ways. ${ }^{1,2}$ Asymmetric rolling with different rotation speeds of the rollers is introduced in Figure 1a. The different speeds of the upper and lower rollers have an impact on the surface of the workpiece. Shear stresses are introduced at speed differences starting from $5 \mathrm{~m} \mathrm{~s}^{-1}$. Asymmetric rolling with a large speed difference between the upper and the lower rollers on a thin workpiece area decreases the shear stresses and establishes normal contact stresses, which is beneficial for achieving the required dimensions. ${ }^{3}$ Rolling with different diameters of rollers (Figure 1b), is asymmetric rolling type, where dimension difference between the upper and the lower rollers results in a very bent workpiece.

*Corresponding author's e-mail:

jakob.kraner@imt.si (Jakob Kraner)
Even very small differences in diameters of the work roller lead to the so-called ski effect. Significant bending is visible at diameter differences of $10 \mathrm{~mm}$. With this kind of asymmetric rolling, the microstructure of the workpiece is more homogeneous because the grain sizes are similar from the centre to the contact surface of the smaller roller. Even finer crystal grains appear on the contact surface of the workpiece and the larger roller. ${ }^{4}$ When rolling with a single drive roller (Figure 1c) is performed, gripping problems of the workpiece occur. Observing the roll gap for the mentioned asymmetric rolling type, it is noticeable that the compressive forces are smaller than in the other presented asymmetric rolling types. The rolling process with a single drive roller results in a microstructure with high shear strains, which can be reduced with the use of lubricants. ${ }^{5}$ With differently lubricated work roller surfaces (Figure 1d) it is also possible to control the bending of the workpiece. In the case of asymmetric rolling, the applied lubricant will have different effects on the lower and upper roller. The 
use of lubricants does not provide a straight asymmetrically rolled workpiece as it influences the formation of the ski effect. ${ }^{6}$ Generally, all four presented asymmetric rolling types are based on kinetic, geometrical or friction changes. ${ }^{7-10}$ In this way the relationship between the roller diameters $(R)$, velocity of rollers $(v)$ and friction factors $(\mu)$ is shown (Figures 1a to $\mathbf{1 d})$.

In Figure $\mathbf{2} \mathbf{a}$ the roll gap of symmetric rolling with marked entry $\left(A_{0}\right.$ and $\left.A_{1}\right)$ and exit $\left(B_{0}\right.$ and $\left.B_{1}\right)$ points is presented. The distance between the entry and exit points represents the length of the deformation zone $l_{\mathrm{d}}{ }^{11}$ In the case of asymmetric rolling with a faster upper roller (Figure 2b), the neutral point of the upper roller, which is with symmetric rolling vertically stationed above lower neutral point, moves closer to the exit of the roll gap. In the same way, the lower neutral point will move in the opposite direction, which is closer to the entry of the deformation zone. Described is a consequence of greater reductions on the upper surface and unchanged energy balance. Between the two differently vertical positioned neutral points, a shear cross-section will be created. The whole plastic deformation zone was divided into three sections, which are in accordance with the direction of the friction forces on the workpiece by the upper and the lower rollers. Section I and Section III represent the entry and exit sections of the roll gap. There, the strains and stresses are normal. Between the differently positioned neutral points, Section II with the shear strains and stresses has appeared. In the case of asymmetric rolling with a higher rotation speed of the lower roller (Figure 2c), the positions of neutral points according to the entry and exit sections will be switched. ${ }^{12,13}$

The major purpose of this investigation was to find and describe the general impact of asymmetric rolling for a chosen aluminium alloy. Asymmetric rolling specific characteristics in comparison with symmetric roll-

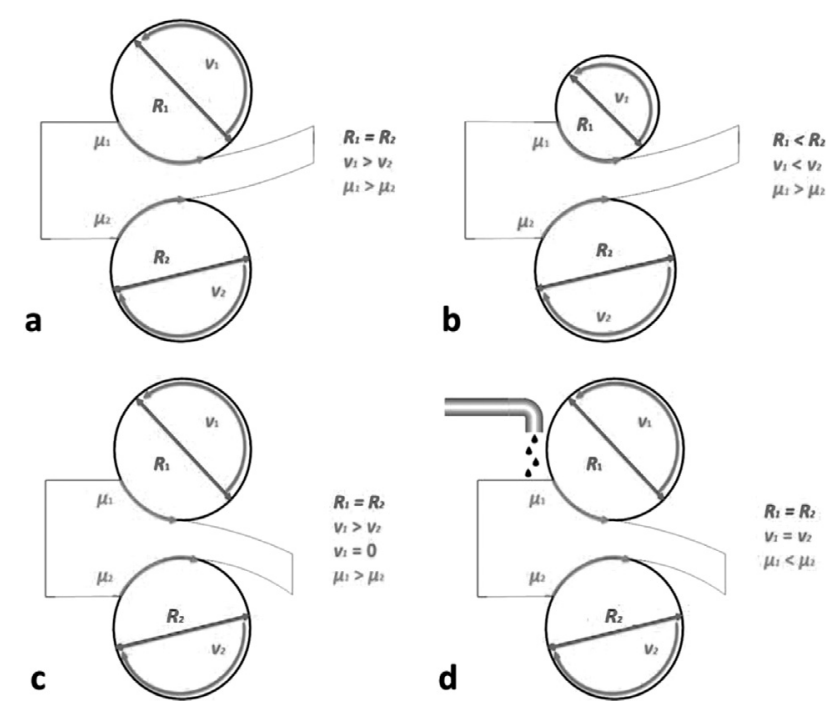

Figure 1: Asymmetric rolling types: a) different rotation speed of rollers, b) different diameters of rollers, c) single drive roller, d) differently lubricated rollers surface ing resulted in a decrease of the rolling force and at the same time with an increase in the strain. With asymmetric rolling more shear strains are created, and that resulted in more heterogeneous texture and lower planar anisotropy after the heat treatment. In only the deformed condition were the tensile and yield strength higher with asymmetric rolling than with symmetric rolling. The microstructure of the asymmetrically rolled sample is more homogeneous than the microstructure of the symmetrically rolled sample, which is confirmed by the finer crystal grains and the evenly distributed hardness in the cross-section. ${ }^{14-16}$

\section{MATERIALS AND METHODS}

Symmetric and asymmetric rolling was performed on the laboratory rolling mill. The roll gap was set at two different heights. The higher set roll gap was $4.0 \mathrm{~mm}$ and the lower set roll gap was $3.1 \mathrm{~mm}$. The plate's entry dimensions were $510 \mathrm{~mm}$ long, $230 \mathrm{~mm}$ wide and $6.7 \mathrm{~mm}$ thick. Expected strains were around $33 \%$ for the higher and $44 \%$ for the lower set roll gap. The rotation speed of the upper and the lower rollers was $10 \mathrm{~min}^{-1}$ during the symmetric rolling. The asymmetry was, in our cases, introduced with different rotation speeds of the work rollers. Two asymmetric rolling types for both mentioned set roll gaps were performed. The asymmetric factor of 1.5 was created with a rotation speed of $15 \mathrm{~min}^{-1}$ for the lower roller and $10 \mathrm{~min}^{-1}$ for the upper roller. For 2.0 factor of asymmetry rotation speed of lower roller was $20 \mathrm{~min}^{-1}$ and $10 \mathrm{~min}^{-1}$ for the upper roller. The rolling plan is presented in Table 1. Numerical simulations with ABAQUS CAE 2018 were created before laboratory rolling for two symmetric and four asymmetric rolling types. Numerical simulations were performed to research the possibilities of asymmetric rolling, compare the ski effect of the simulated and laboratory rolled plates and study the stress condition in the deformation zone. For the numerical simulations the presented entry dimensions of plates, roller dimensions, rolling parameters and material properties were considered. The maximum achieved rolling force and torque were record during the laboratory rolling. According to the entry and exit plate dimensions, the thickness reduction and the deformation

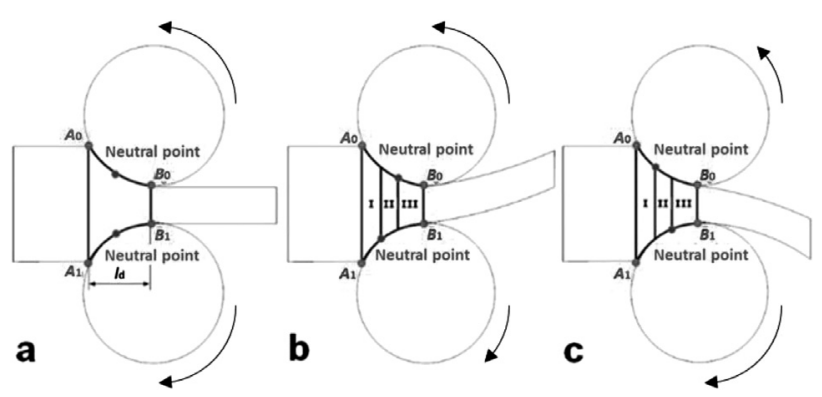

Figure 2: Deformation zone: a) symmetric rolling, b) asymmetric rolling with faster upper roller, c) asymmetric rolling with faster lower roller 
were calculated. The undesired ski effect was analysed by measuring the length of the bended area and the angle of curvature. Three plates were rolled for each of the six different rolling types. That way enough material for different mechanical tests was produced. Mechanical tests and microstructure characterization were performed on the deformed as well as the heat-treated samples. The heat treatment involved heating and holding material at $400{ }^{\circ} \mathrm{C}$ for $1 \mathrm{~h}$, achieving the soft condition of material, and the air cooling. Changes of the mechanical properties were observed with the results of tension test, where the tensile strength, yield strength and elongations were acquired. Samples for tension tests were taken in three different directions according to rolling direction. Samples in the rolling direction $\left(0^{\circ}\right)$, transverse direction $\left(90^{\circ}\right)$ and diagonal direction $\left(45^{\circ}\right)$ were also taken for the plastic strain ratio test. From the mentioned mechanical test, which is an alternative for the Erichsen test, the Lankford factor was calculated as indicator of anisotropy. The Brinell hardness was measured on the top, centre and bottom positions of each sample's cross-section. In the mentioned sections, the grain size was measured using a light microscope (LM). A scanning electron microscope (SEM) with electron backscatter diffraction (EBSD) was used for the texture analyses of different rolled and heat-treated samples. Samples for LM and SEM were metallographically prepared by mechanically grinding and polishing. The last surface preparation step was polishing for $10 \mathrm{~min}$ with OPS and 50 min ion etching. Figure 3 presents the laboratory rolling mill working area, numerically simulated and deformed plates.

Table 1: Rolling plan

\begin{tabular}{|c|c|c|c|}
\hline & Type & $\begin{array}{c}\text { Lower roller velocity } \\
n_{1} / \text { Upper roller ve- } \\
\text { locity } n_{\mathrm{u}}\left(\mathrm{min}^{-1}\right)\end{array}$ & $\begin{array}{c}\text { Factor of } \\
\text { asymmetry }\end{array}$ \\
\hline \multirow{2}{*}{$\begin{array}{c}\text { Roll gap set } \\
s_{0}: 4.0 \mathrm{~mm}\end{array}$} & 1 & $10 / 10$ & 1.0 \\
\cline { 2 - 4 } & 2 & $15 / 10$ & 1.5 \\
\cline { 2 - 4 } & 3 & $20 / 10$ & 2.0 \\
\hline \multirow{2}{*}{$\begin{array}{c}\text { Roll gap set } \\
s_{0}: 3.1 \mathrm{~mm}\end{array}$} & 4 & $10 / 10$ & 1.0 \\
\cline { 2 - 4 } & 5 & $15 / 10$ & 1.5 \\
\hline
\end{tabular}

\section{RESULTS AND DISCUSSION}

\subsection{Numerical simulation}

With numerical simulations the major emphasis was on the appearance of the ski effect and stress condition differences in the deformation zone. The same as with laboratory rolling, the unwanted ski effect was formed only with asymmetric rolling simulations. A numerical simulation for the symmetrical type is presented in Figure 4a and for the same set roll gap the asymmetric type of rolling is presented in Figure $\mathbf{4 b}$. More differences can be observed comparing the deformation zones from the entry to the exit of the roll gap. In Figure 5a the
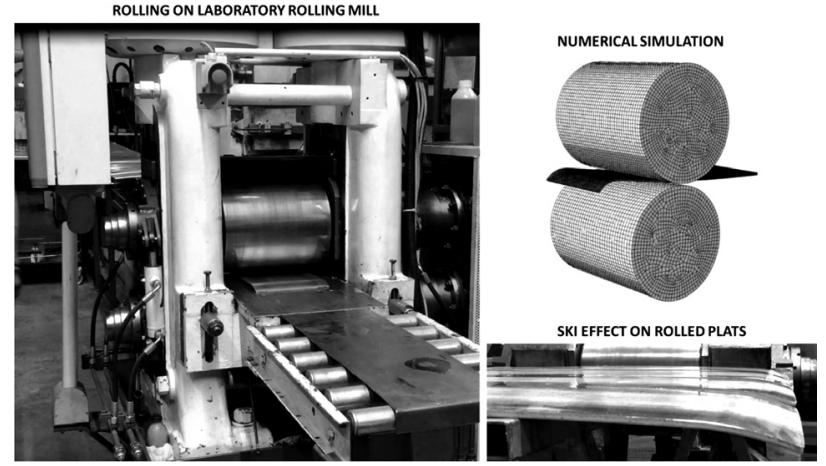

Figure 3: Experimental part with laboratory rolling mill, numerical simulation and analysed rolled plates

stress condition of the symmetric rolling is presented. The higher stresses are evenly distributed for the upper and lower rollers. Stresses distribution on entry to the deformation zone is vertical. The same oriented stresses are created on exit from the deformation zone with symmetric rolling. Generally, higher values of stresses are observed with symmetric than with asymmetric rolling. The created stress condition in the deformation zone with asymmetric rolling (Figure 5b) is at entry area quite similar to the symmetric. After the vertical distributed the stresses cross shape distribution follows. It is clear that slightly higher stresses are created near the faster, lower roller. With asymmetrical rolling, upon the exit, stresses are vertically orientated only on the rollers' contact with the workpiece, whereas in the cross-section, shear orientated stresses as a connection to vertical stresses were created. ${ }^{17}$

\subsection{Technological parameters}

Calculated reductions and strains increased with a higher factor of asymmetry. That is confirmed at the higher as well as at the lower set roll gap. A correlation

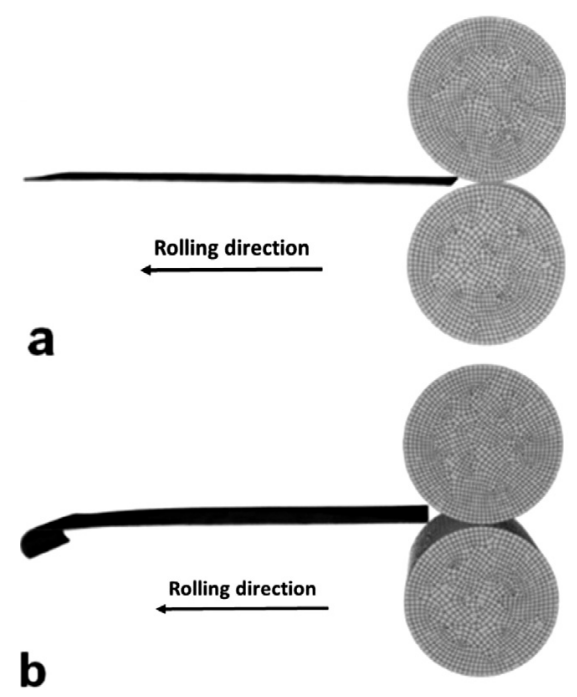

Figure 4: Numerical simulation: a) symmetric rolling, b) asymmetric rolling 


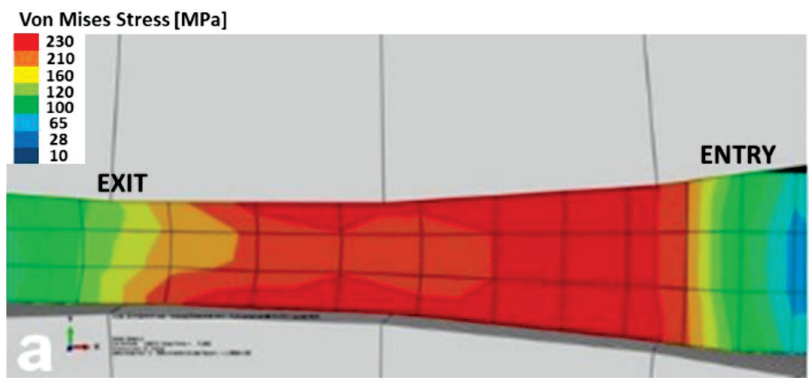

Von Mises Stress [MPa]

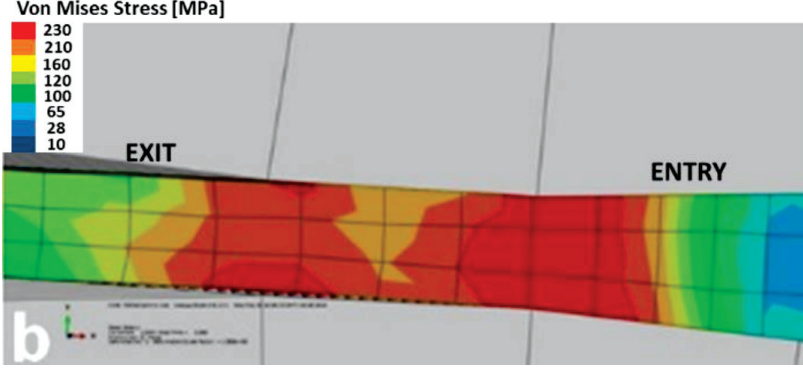

Figure 5: Stress condition in deformation zone: a) symmetric rolling, b) asymmetric rolling

between the maximum reached rolling forces and the strains for separate rolling types is presented in Table 2. With $4.0 \mathrm{~mm}$ set roll gap rolling forces with belonging strain were $1128 \mathrm{kN}$ and $30.6 \%$ for factor of asymmetry $1.0,1099 \mathrm{kN}$ and $31.4 \%$ for factor of asymmetry 1.5 and $1083 \mathrm{kN}$ and $31.5 \%$ for factor of asymmetry 2.0. At 3.1 $\mathrm{mm}$ set roll gap the rolling forces are higher and the strains are larger. The difference between the symmetric and asymmetric maximum rolling force is higher for the lower set roll gap. But at the same time, the difference between the achieved strains, with two asymmetric types at lower set roll gap, is smaller. More specific are the rolling forces and strains at $3.1 \mathrm{~mm}$ set roll gap, which are $1377 \mathrm{kN}$ and $42.7 \%$ for factor of asymmetry 1.0, $1341 \mathrm{kN}$ and $44.9 \%$ for factor of asymmetry 1.5 and $1309 \mathrm{kN}$ and $44.9 \%$ for factor of asymmetry 2.0.

Table 2: Measured rolling forces and calculated strains

\begin{tabular}{|c|c|c|c|}
\hline & $\begin{array}{c}\text { Factor of asym- } \\
\text { metry }\end{array}$ & $\begin{array}{c}\text { Rolling force } \\
(\mathrm{kN})\end{array}$ & $\begin{array}{c}\text { Strain } \\
(\%)\end{array}$ \\
\hline \multirow{2}{*}{ Roll gap set } & 1.0 & 1128 & 30.6 \\
\cline { 2 - 4 }$s_{0}: 4.0 \mathrm{~mm}$ & 1.5 & 1099 & 31.4 \\
\cline { 2 - 4 } & 2.0 & 1083 & 31.5 \\
\hline \multirow{2}{*}{$\begin{array}{c}\text { Roll gap set } \\
s_{0}: 3.1 \mathrm{~mm}\end{array}$} & 1.0 & 1377 & 42.7 \\
\cline { 2 - 4 } & 1.5 & 1341 & 44.9 \\
\hline
\end{tabular}

A decrease of the rolling force and an increase of the strain are the major technological advantages of asymmetric rolling. In the possible case of rolling with more passes, fewer passes would be needed to reach the desired final thickness. There is also an economic impact that can be exposed, where fewer production steps bring lower costs and less wear of the rolling mill. ${ }^{14,15}$
The length and angle of the bended part were measured on three plates, rolled with the same rolling type and interpreted as ski effect. Average length as well as the angles have shown that the factor of asymmetry has a higher impact on the formation of a larger ski effect than strain. For a factor of asymmetry 1.5 for both set roll gaps the lengths were $57.0 \mathrm{~mm}$ with an angle of $18.3^{\circ}$ and $57.6 \mathrm{~mm}$ with an angle of $19^{\circ}$, and for factor of asymmetry 2.0 lengths of ski effect were $60.3 \mathrm{~mm}$ with angle $20.3^{\circ}$ and $63.6 \mathrm{~mm}$ with angle $21^{\circ}$. The described ski effect is presented in Table 3 .

Table 3: Ski effect depending on the initial rolling settings

\begin{tabular}{|c|c|c|c|}
\hline & $\begin{array}{c}\text { Factor of } \\
\text { asymmetry }\end{array}$ & $\begin{array}{c}\text { Length of } \\
\text { bended part } \\
(\mathrm{mm})\end{array}$ & $\begin{array}{c}\text { Angle of cur- } \\
\text { vature }\left(^{\circ}\right)\end{array}$ \\
\hline \multirow{2}{*}{$\begin{array}{c}\text { Roll gap set } \\
s_{0}: 4.0 \mathrm{~mm}\end{array}$} & 1.0 & 0 & 0 \\
\cline { 2 - 4 } & 1.5 & 57.0 & 18.3 \\
\hline \multirow{2}{*}{$\begin{array}{c}\text { Roll gap set } \\
s_{0}: 3.1 \mathrm{~mm}\end{array}$} & 2.0 & 60.3 & 20.3 \\
\cline { 2 - 4 } & 1.0 & 0 & 0 \\
\hline
\end{tabular}

The major problem for asymmetric rolling with more passes is the ski effect. In Figure 6 is compared an appearance of ski effect with a faster upper (mark a) and a faster lower roller (mark b). Differences are clearly visible, especially because rolling with a faster upper roller produces useless material for the mechanical tests. Nevertheless, that ski effect is an expected consequence of asymmetric rolling. The bended area can be compensated with the usually cut off the head and the foot of the rolled workpiece. The higher deformation with asymmetric rolling in the end also produces longer workpieces. ${ }^{18}$

\subsection{Mechanical properties and microstructure}

The tensile strength $R_{\mathrm{m}}$, yield strength $R_{\mathrm{p} 0.2}$ and elongation $A_{25 \mathrm{~mm}}$ values were presented as results of tensile tests. Average values of three samples taken in different directions $\left(0^{\circ}, 45^{\circ}\right.$ and $\left.90^{\circ}\right)$ for samples in deformed and heat-treated conditions are presented in Table 4 . For the deformed samples the $R_{\mathrm{m}}$ values are higher at asymmet-

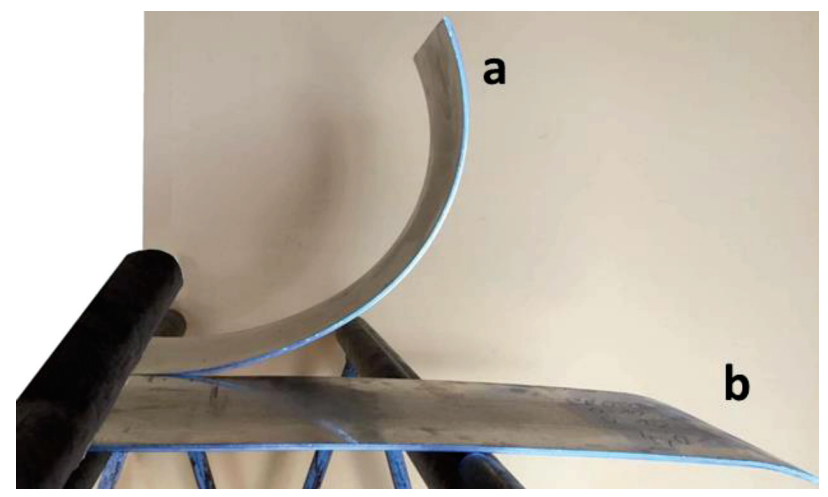

Figure 6: Difference between plates rolled with faster upper roller (mark a) and faster lower roller (mark b) 
ric rolling types than for symmetric rolling types. At 4.0 $\mathrm{mm}$ set roll gap average $R_{\mathrm{m}}$ is $280 \mathrm{MPa}$ for 1.5 and 2.0 factors of asymmetry. The highest $R_{\mathrm{m}}$ values are in the transverse direction $\left(90^{\circ}\right)$. For a $3.1 \mathrm{~mm}$ set roll gap the highest value is $293 \mathrm{MPa}$ for a 1.5 factor of asymmetry. After the heat treatment the $R_{\mathrm{m}}$ values are around 218 $\mathrm{MPa}$ for all the performed rolling types. The highest $R_{\mathrm{p} 0.2}$ values were observed in the rolling direction $\left(0^{\circ}\right)$ for all six different rolling types. The deformed samples with the lower set roll gap have the highest average $R_{\mathrm{p} 0.2}$. In general, the $R_{\mathrm{p} 0.2}$ values are higher for the asymmetric rolled samples. For the higher set roll gap, $R_{\mathrm{p} 0.2}$ is lower by a 1.5 factor of asymmetry than with symmetric rolling (1.0). After the heat treatment all $R_{\mathrm{p} 0.2}$ values are between $86 \mathrm{MPa}$ and $90 \mathrm{MPa}$. $A_{25 \mathrm{~mm}}$ values are at asymmetric rolling for both set roll gaps the same or slightly lower compared with symmetric rolling types. The $A_{25 \mathrm{~mm}}$ values are between $10 \%$ and $12 \%$ for $4.0 \mathrm{~mm}$ set roll gap and $8 \%$ to $9 \%$ for $3.1 \mathrm{~mm}$ set roll gap. All the heat-treated samples have an $A_{25 \mathrm{~mm}}$ average value $29 \%$ to $30 \%$ for 1.5 factor of asymmetry. The highest $A_{25 \mathrm{~mm}}$ values are observed after heat treatment in diagonal direction $\left(45^{\circ}\right)$.

Average values of Lankford factor $r_{\mathrm{m}}$ have been calculated with Equation (1):

$$
r_{\mathrm{m}}=\frac{\left(r_{0}+2 r_{45}+r_{90}\right)}{4}
$$

and with tendency of plastic strain ratio $\Delta r$ calculated with Equation (2):

$$
r_{\mathrm{m}}=\frac{\left(r_{0}+r_{90}-2 r_{45}\right)}{2}
$$

and is an indicator for planar anisotropy. For both set roll gaps the $r_{\mathrm{m}}$ values increase with a higher factor of asymmetry for deformed samples. For heat-treated samples is just the opposite. There, the $r_{\mathrm{m}}$ values are smaller for the asymmetric rolled samples. For the deformed samples the $r_{\mathrm{m}}$ values are between $0.49 \mathrm{~mm}$ and 0.55 $\mathrm{mm}$ for $4.0 \mathrm{~mm}$ set roll gap and between $0.33 \mathrm{~mm}$ and $0.41 \mathrm{~mm}$ for $3.1 \mathrm{~mm}$ set roll gap. Slightly higher are the $r_{\mathrm{m}}$ values after the heat treatment. They are between 0.56 and 0.62 for the higher set roll gap and between
0.67 and 0.79 for lower set roll gap. The increase and decrease of the $r_{\mathrm{m}}$ values is correlated to the $\Delta r$ values. All the $\Delta r$ values are negative and even more negative after heat treatment for more deformed samples. Least negative $\Delta r$ values were calculated for $3.1 \mathrm{~mm}$ set roll gap at both asymmetric rolling types. For factor of asymmetry $1.5 \Delta r$ is -0.052 and -0.050 for 2.0 . All the $r_{\mathrm{m}}$ and $\Delta r$ values are presented in Table 4.

Asymmetric rolling produces better mechanical properties compared to symmetric rolling after heat treatment to the soft condition. A very low planar anisotropy appeared near areas with higher tensile and yield strength after just deformation. The lower planar anisotropy, which appears at higher strains, is a great indicator for successful heat treatment. ${ }^{14,15}$ Brinell hardness (HB) and average crystal grains sizes are present together in Figure 7. More than relatively high hardness values is important that the differences through the cross-section for asymmetric rolled samples are smaller. The average hardness for the deformed samples is for both set roll gaps between $84 \mathrm{HB}$ and $88 \mathrm{HB}$. Hardness values are after heat treatment much lower $(56 \mathrm{HB})$. In accordance with more similar hardness values through the cross-section with asymmetric rolled samples are also the average crystal grains size. The crystal grains created with asymmetric rolling are smaller than with symmetric rolling. Smaller crystal grains appeared on contacts with both rollers (bottom and top of cross-section). That is very similar also for the hardness for all the rolling types. All the rolling types, with both set roll gaps and in all three cross-section positions, have average crystal grains sizes between $17.5 \mu \mathrm{m}$ and $26.4 \mu \mathrm{m}$ for the deformed and 19.2 $\mu \mathrm{m}$ and $33.9 \mu \mathrm{m}$ for the heat-treated samples. With asymmetric rolling a smaller central band of longitudinal deformed crystal grains is formed. After heat treatment to the soft condition the differences of crystal grain sizes on contact and in centre position remained. Grains of symmetric rolled samples were bigger in all three measured positions in comparison to the asymmetric rolling type. Besides the low planar anisotropy, more homoge-

Table 4: Results of tensile test and plastic strain ratio test

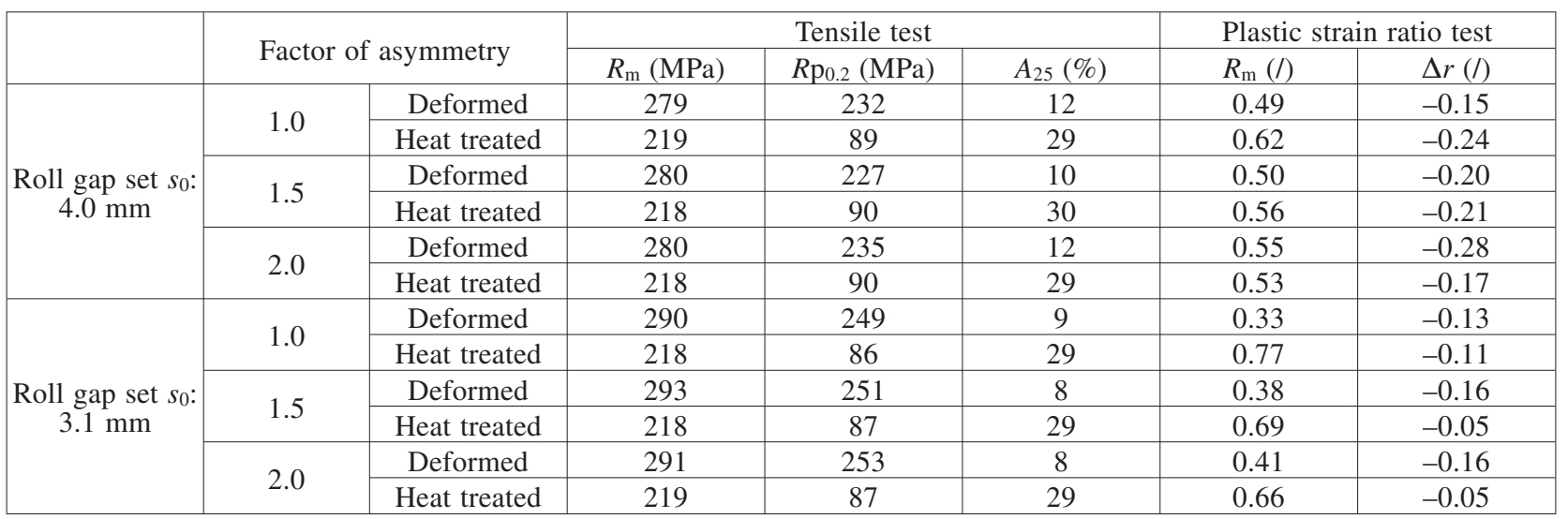




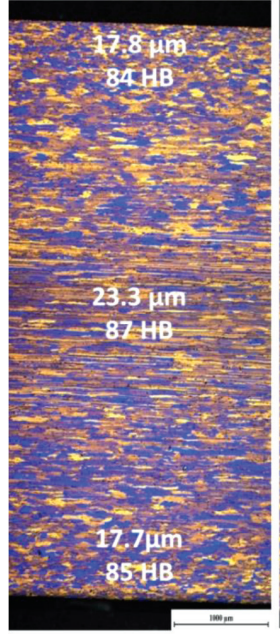

Symmetric rolled Deformed condition

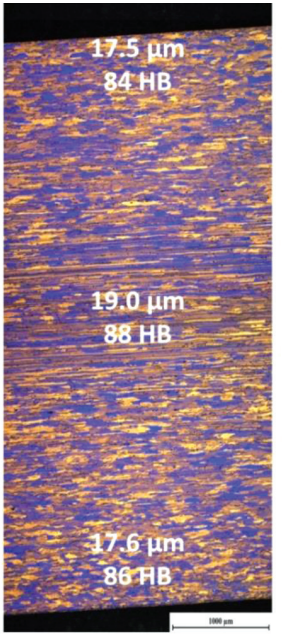

Asymmetric rolled Deformed condition

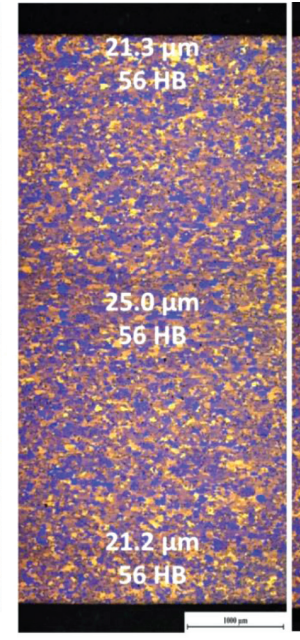

Symmetric rolled Heat-treated

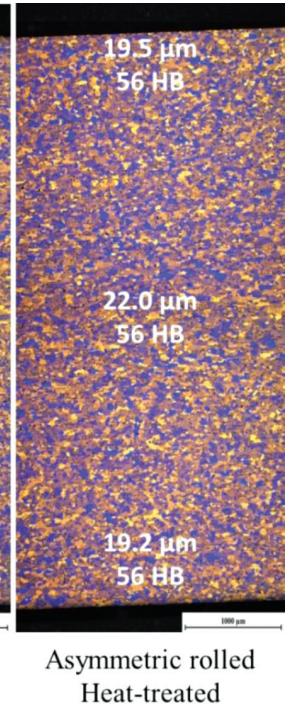

Figure 7: Microstructures of symmetric and asymmetric rolled samples in cross-section in deformed and heat-treaded condition with average grain size and Brinell hardness

neous material is a key preference for asymmetric rolling. Smaller differences of hardness and average grain size in the cross-section are a good indicator for the evenly distributed mechanical properties. ${ }^{7,8,18-20}$

\subsection{Textures}

Detected and measured were four rolling, three shear and five recrystallized texture components. All twelve texture components are common in aluminium alloy textures and were chosen to make a detailed description of the crystallographic texture. ${ }^{18,20} \mathrm{~A}$ comparison of the detected volume fraction of each texture component for symmetric and asymmetric rolled samples was made. A comparison of the textures of the deformed and heat-treated samples shows that in most cases only one or a maximum of up to three texture components were detected in the deformed sample texture. On the other hand, in all the observed heat-treated samples, all twelve developed texture components were detected. More expressed pole figures are presented in Figure 8a, where only the recrystallization texture component $\mathrm{P}$ with higher volume fraction $4.9 \%$ was detected. In the same heat-treated sample (Figure 8b) all the texture components have volume fractions between $0.2 \%$ and $2.4 \%$. Comparing the symmetric and asymmetric rolled and heat-treated samples it is clear that a higher volume fraction of shear texture components and a more evenly distributed volume fraction of all texture components appeared in the asymmetric rolled textures (samples).
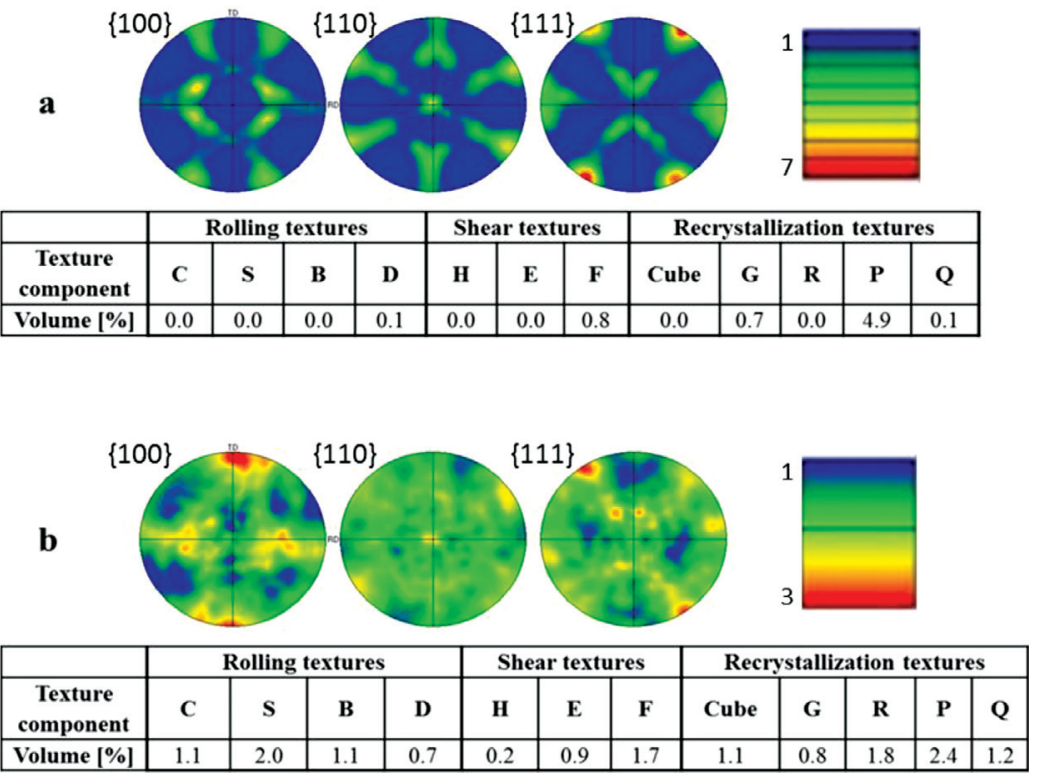

Figure 8: Texture components presented with pole figures and volume fraction: a) deformed condition, b) heat-treated condition 
The texture analyses and the determination of the volume fraction for separate texture components is very important and in conjunction with a successful heat treatment. Changes in the textures appear at each step of metallurgical processes. Tracking the history of material textures is very important, because higher volume fractions of texture components can be produced at the beginning of the process and cannot be removed with different operations until the end. ${ }^{22-25}$

\section{CONCLUSIONS}

The impact of asymmetric cold rolling was investigated on the EN AW 5454 aluminium alloy. Symmetric and asymmetric rolled plates were compared by using different technological rolling parameters, the mechanical properties and the microstructure characteristics. Mechanical tests and microstructure analyses were performed on deformed and heat-treated samples. Numerical simulations showed that the ski effect appeared only with asymmetric rolling and that the stress conditions in the deformation zone were different when comparing symmetric and asymmetric rolling. Asymmetric rolling produced higher strains with a lower rolling force at the same set roll gap. Rolling forces decreased and achieved strains increased with a higher factor of asymmetry. The ski effect depends more on the factor of asymmetry than on the strain. The tensile strength and yield strength increased with a higher factor of asymmetry. The effectiveness of heat treatment is shown in similar elongations of the samples. The elimination of planar anisotropy after heat treatment was higher with asymmetrically rolled samples and with a higher factor of asymmetry. Asymmetrically rolled samples have a smaller deviation of the hardness than the symmetrically rolled samples. The hardness of the asymmetrically rolled samples was also more homogenous after the heat treatment. The average crystal grain size decreased with a higher factor of asymmetry. A higher volume fraction of the shear and rolling texture components was found after heat treatment in the texture of the asymmetrically rolled samples. The obtained volume fractions of texture components emphasize more with symmetrically rolled samples, which has an impact on the anisotropy.

\section{Acknowledgment}

The authors acknowledge the financial support from the Slovenian Research Agency, research core funding's No. P2-0132 and No. P2-0344. We gratefully acknowledge the financial support of the Republic of Slovenia Ministry of Education, Science and Sport and of the European Union - the European Regional Development Fund, which enabled the MARTIN programme (grant number OP20.03531), in the framework of which the presented work was carried out, to be conducted.
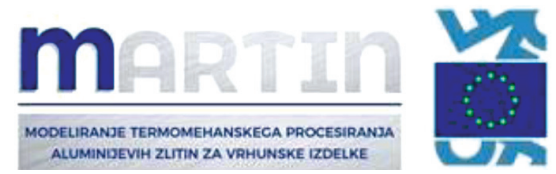

EVROPSKA UNIJA

EVROPSKI SKLAD ZA REGIONALNI RAZVO:

\section{REFERENCES}

${ }^{1}$ F. J. P. Simoes, R. J. Alves de Sousa, J. J. A. Gracio, F. Barlat, J. Whan Yoon, Mechanical behaviour of an asymmetrically rolled and annealed 1050-O sheet, Int. J. Mech. Sci., 50 (2008) 1372-1380, doi:10.1016/j.ijmecsci.2008.07.009

${ }^{2}$ S. Ucuncuoglu, A. Ekerim, G. O. Secgin, O. Duygulu, Effect of asymmetric rolling process on the microstructure, mechanical properties and texture of AZ31 magnesium alloys sheets produced by twin roll casting technique, J. Mag. All., 2 (2014) 92-98, doi:10.1016/j.jma.2014.02.001

${ }^{3}$ V. Alexa, S. Ratiu, I. Kiss: Metal rolling - Asymmetrical rolling process, IOP Cof. Series: Mater. Sci. Eng., Wuhan, 2015, 1-10, doi:10.1088/1757-899X/106/1/012019

${ }^{4}$ Y.-M. Hwang, G.-Y. Tzou, Analitycal and exprerimental study on asymmetrical sheet rolling, Int. J. Mech. Sci., 39 (1997) 289-303, doi:10.1016/S0020-7403(96)00024-0

${ }^{5}$ A. Bintu, G. Vincze, R. C. Picu, A. B. Lopes, Effect of symmetric and asymmetric rolling on the mechanical properties of AA5182, Mat. Des., 100 (2016) 151-156, doi:10.1016/j.matdes.2016.03.123

${ }^{6} \mathrm{H}$. Utsunomiya, T. Ueno, T. Sakai, Improvement in the r-value of aluminium sheets by differential-friction rolling, Scri. Mat., 57 (2007) 1109-1112, doi:10.1016/j.scriptamat.2007.08.024

${ }^{7}$ A. Nillson, I. Isalvator, P.-D. Putz, G. Goldhahn, J. Malbrancke: Using asymmetrical rolling for increased production and improved material properties. https://publications.europa.eu/en/publication-detail/-/publication/92f3642d-cec8-4f36-bd11-ec9e82ec44de/language-en, 24.1.2019 doi:10.2777/14782

${ }^{8}$ J. J. Minton, C. J. Cawthorn, E. J. Brambley, Asymptotic analysis of asymmetric thin sheet rolling, Int. J. Mech. Sci., 113, (2016) 36-48, doi:10.1016/j.ijmecsci.2016.03.024

${ }^{9}$ P. Fajfar, A. Šalej Lah, J. Kraner, G. Kugler, Asymmetric rolling process, Mater. Geoenv., 64 (2017) 151-160, doi:10.1515/rmzmag2017-0014

${ }^{10}$ W. Polkowski, Differential Speed Rolling: A new method for a fabrication of metallic sheets with enhanced mechanical properties, progress in metallic Alloys, London 2016, doi:10.5772/64418

${ }^{11}$ V. A. Nikolaev, A. A. Vasilyev: analysis of strip asymmetric cold rolling parameters. http://metaljournal.com.ua/assets/Uploads/attachments/Nikolaev405.pdf 24.1.2019

${ }^{12}$ P. P. Gudur, M. A. Salunkhe, U. S. Dixit, A theoretical study on the application of asymmetric rolling for the estimation of friction, Int. J. Mech. Sci., 50 (2008) 315-327, doi:10.1016/j.ijmecsci.2007.06.002

${ }^{13}$ H. B. Xie, K. Manabe, Z.Y. Jiang, A novel approach to investigate surface roughness evolution in asymmetric rolling based in three dimensional real surface, Fin. Elem. Anal. Des., 74 (2013) 1-8, doi:10.1016/j.finel.2013.05.010

${ }^{14}$ K. -H. Kim, D. N. Lee, C. -H. Choi: The deformation textures and Lankford values of asymmetrically rolled aluminium alloy sheet. Proc. Int. Conf. Tex. Mat., Montreal, 1999, 755-760

${ }^{15}$ B.-H. Cheon, H.-W. Kim, J.-C. Lee, Asymmetric rolling of strip-cast Al-5.5Mg-0.3Cu alloy sheet: Effect on the formability and mechanical properties, Mat. Sci. Eng. A, 528 (2011) 5223-5227, doi:10.1016/j.msea.2011.03.021

${ }^{16}$ F. Shen, D. Yi, Y. Jiang, B. Wang, H. Liu, C. Tang, W. Shou, Semi-quantitative evolution of texture components and fatigue properties in 2524 T3 aluminum alloy sheets, Mater. Sci. Eng. A, 657 (2016) 15-25, doi:10.1016/j.msea.2016.01.026

${ }^{17}$ S. Tamini, J. P. Correia, A. B. Lopes, S. Ahzi, F. Barlat, J. J. Gracio, Asymmetric rolling of thin AA-5182 sheets: Modelling and experi- 


\section{J. KRANER et al.: ASYMMETRIC COLD ROLLING OF AN AA 5xxx ALUMINIUM ALLOY}

ments, Mater. Sci. Eng. A, 603 (2014) 150-159, doi:10.1016/ j.msea.2014.02.048

${ }^{18}$ J. Kraner, P. Fajfar, H. Palkowski, G. Kugler, M. Godec, I. Paulin, Microstructure and texture evolution with relation to mechanical properties of compared symmetrically and asymmetrically Cold Rolled Aluminium, Metals, 10 (2020) 156, doi:10.3390/ met 10020156

${ }^{19}$ J. Kraner, P. Fajfar, H. Palkowski, M. Godec, I. Paulin, Asymmetric cold rolling of specific aluminium alloy, XXXVIII. Verformungskundliches Kolloquium, Zauchensee, 2019, 88-93

${ }^{20}$ J. Sidor, A. Miroux, R. Petrov, L. Kestens, Mirostructural and crystallographic aspect of conventional and asymmetric rolling processes, Acta Mater., 56 (2008) 2495-2507, doi:10.1016/j.actamat. 2008.01.042

${ }^{21}$ D. Anders, T. Münker, J. Artel, K. Weinberg, A dimensional analysis of front-end bending in plate rolling applications, J. Mat. Proc. Tech., 212 (2012) 1387-1398, doi:
${ }^{22}$ J.-H. Han, J.-Y. Suh, K. H. Oh, J. -C. Lee, Effects of the deformation history and the initial textures on the texture evolution in an $\mathrm{Al}$ alloy strip during the shear deforming process, Acta Mat., 52 (2004) 4907-4918, doi:10.1016/j.actamat.2004.06.045

${ }^{23}$ J. Kraner, P. Fajfar, H. Palkowski, M. Godec, I. Paulin, Comparison of symmetric and asymmetric rolling for AA 5454 aluminium alloy, $11^{\text {th }}$ International Rolling Conference (IRC 2019), Sao Paulo 2019, doi: $10.5151 / 9785-9785-32463$

${ }^{24} \mathrm{~S}$. Wronski, B. Bacroix, Microstructure evolution and grain refinement in asymmetrically rolled aluminium, Acta Mater., 76 (2014) 404-412, doi:10.1016/j.actamat.2014.05.034

${ }^{25}$ J. Sidor, R. H. Petrov, L. A. I. Kestens, Deformation, recrystallization and plastic anisotropy of asymmetrically rolled aluminum sheets, Mater. Sci. Eng. A, (2010), doi:10.1016/j.msea.2010.09.023 